\title{
Profil Pengetahuan Guru Sekolah Dasar tentang Higher Order Thinking Skill dalam Pembelajaran Matematika
}

\author{
${ }^{1}$ Rafiq Badjeber, ${ }^{2}$ Nursupiamin, ${ }^{3}$ Agung Wicaksono, ${ }^{4}$ Mufidah \\ ${ }^{1}$ Tadris Matematika, Fakultas Tarbiyah dan IImu Keguruan, IAIN Palu \\ Jl. Diponegoro No.23, Palu, Sulawesi Tengah \\ Email: rafiq_badjeber@iainpalu.ac.id
}

Article History:

Received: 03-08-2020; Received in Revised: 30-09-2020; Accepted: 02-10-2020

\begin{abstract}
Higher-order thinking skills are the abilities needed in preparing students to face global challenges. This research aims to describe the profile of elementary school teacher knowledge about higher-order thinking skills in mathematics learning. The research is a descriptive study with a qualitative approach. The subjects in this research consisted of 3 elementary school teachers in Palu. Data collection was carried out through questionnaires and interviews. The results indicate that not all teachers can interpret higher-order thinking skills well. The teacher's knowledge about the implementation of mathematics learning which is oriented higher-order thinking skills is also still low.
\end{abstract}

Keywords: Teacher's Knowledge; Higher Order Thinking Skill; Mathematics Learning.

\begin{abstract}
Abstrak
Higher order thinking skill merupakan kemampuan yang dibutuhkan dalam mempersiapkan peserta didik untuk menghadapi tantangan global. Penelitian ini bertujuan untuk mendeskripsikan profil pengetahuan guru SD tentang higher order thinking skill dalam pembelajaran matematika. Penelitian yang dilakukan merupakan penelitian deskriptif dengan pendekatan kualitatif. Subjek dalam penelitian ini terdiri dari 3 orang guru Sekolah Dasar yang berada di kota Palu. Pengumpulan data dilakukan melalui kuesioner dan wawancara. Hasil penelitian yang diperoleh menunjukkan bahwa tidak semua guru mengetahui makna higher order thinking skill dengan baik. Pengetahuan guru tentang implementasi pembelajaran matematika yang berorientasi higher order thinking skill juga masih rendah.
\end{abstract}

Kata Kunci: Pengetahuan Guru; Higher Order Thinking Skill; Pembelajaran Matematika. 


\section{Pendahuluan}

Abad ke-21 yang penuh dengan tantangan termasuk dalam bidang pendidikan menuntut untuk bisa mempersiapkan sumber daya manusia yang kritis, kreatif, dan inovatif. Cara yang dapat ditempuh untuk dapat mencapai tujuan tersebut, diantaranya melalui peningkatan mutu pendidikan. Dibutuhkan pendidikan yang mengintegrasikan kecakapan pengetahuan, keterampilan dan sikap serta dibarengi dengan penguasaan teknologi. Kecakapan tersebut dapat ditingkatkan diantaranya melalui kegiatan pembelajaran yang dapat memfasilitasi peserta didik untuk mengembangkan bakat dan kemampuannya secara mandiri dengan bantuan guru. Kecakapan yang dibutuhkan di abad 21 ini yang meliputi keterampilan berpikir kritis, memecahkan masalah, berkomunkasi dan berkolaborasi merupakan keterampilan berpikir tingkat tinggi (higher order thinking skill) yang sangat dibutuhkan dalam mempersiapkan peserta didik untuk menghadapi tantangan global ${ }^{1}$.

Sekolah Dasar (SD) merupakan strata pendidikan awal yang wajib ditempuh oleh setiap anak di Indonesia. Ibarat sebuah rumah, Sekolah Dasar merupakan pondasi yang harus diperkokoh agar dapat menopang anak dalam menempuh pendidikan di jenjang berikutnya. Kemampuan yang dimiliki setiap anak harus dapat dikembangkan dan difalisitasi secara optimal sejak dini termasuk kemampuan matematisnya. Namun, laporan Trends in International Mathematics and Science Study (TIMSS) ${ }^{2}$ dan Lynch School of Education pada tahun 2015, menempatkan penguasaan kemampuan matematis anak kelas 4 SD di Indonesia pada urutan ke 45 dari 50 negara dengan perolehan skor 397. Hasil ini tentu bukan merupakan suatu hal yang dapat dibanggakan. Diperlukan berbagai pembenahan agar dapat melakukan perbaikan atas hasil tersebut khususnya pada tingkat Sekolah Dasar (SD).

Suherman, dkk ${ }^{3}$ menyatakan bahwa matematika penting untuk dipelajari karena selain berfungsi sebagai ilmu juga sebagai alat dan pola pikir. Secara umum, pembelajaran matematika memiliki visi diantaranya adalah memberikan kemampuan bernalar secara logis, sistematis, kritis dan cermat, mengembangkan kepercayaan serta sikap objektif dan terbuka ${ }^{4}$. Dalam proses

1 Partnership for 21St Century Skills, "Framework for 21st Century Learning," Partnership for 21st Century Skills, https://doi.org/http://www.21stcenturyskills.org/documents/framework_flyer_updated_ja n_09_final-1.pdf.

2 Liv Sissel Gronmo et al., "TIMMS 2015 Mathematics Framework," TIMSS 2015 International Results in Mathematics, 2016.

3 Maya Kusumaningrum and Adul Aziz Saefudin, "Mengoptimalkan Kemampuan Berpikir Matematika Melalui Pemecahan Masalah Matematika," Prosiding Kontribusi Pendidikan Matematika Dan Matematika Dalam Membangun Karakter Guru Dan Siswa, 2012.

${ }^{4}$ Heris Hendriana and Utari Sumarmo, Penilaian Pembelajaran Matematika, PT Refika Aditama, 2017. 
pembelajaran matematika, siswa dilatih untuk dapat berpikir dan bernalar dalam membuat suatu generalisasi melalui kegiatan penyelidikan, eksplorasi, maupun eksperimen. Kemampuan-kemampuan yang menjadi tuntutan dalam pembelajaran matematika tersebut merupakan representasi dari higher order thinking skill.

Higher order thinking skill menghendaki seseorang untuk menggunakan informasi atau pengetahuan yang telah dimiliki dan memanipulasinya untuk memperoleh solusi dalam situasi permasalahan yang baru ${ }^{5}$. Brookhart ${ }^{6}$ menyatakan bahwa higher order thinking skill (HOTS) berkenaan dengan tiga hal, yaitu transfer (HOTS as transfer), berpikir kritis (HOTS as critical thinking), dan pemecahan masalah (HOTS as problem solving). Transfer merupakan kemampuan memanfaatkan dan mengaplikasikan informasi yang telah dimiliki ke dalam konteks yang baru. Berpikir kritis merupakan cara berpikir rasional dan reflektif yang difokuskan pada pengambilan keputusan berdasarkan alasan yang logis dan ilmiah7 ${ }^{7}$ Sedangkan, pemecahan masalah mengacu pada kemampuan mengidentifikasi dan menyelesaikan masalah menggunakan strategi nonrutin. Anderson \& Krathwohl ${ }^{8}$, mengemukakan bahwa dimensi proses berpikir Taksonomi Bloom meliputi (1) mengingat (remember-C1); (2) memahami (understand-C2); (3) mengaplikasikan (apply-C3); (4) menganalisis (analysis-C4); (5) mengevaluasi (evaluate-C5); dan (6) mencipta/mengkreasi (create-C6). Kemampuan yang melibatkan menganalisis, mengevaluasi dan mencipta/mengkreasi inilah yang dinamakan keterampilan berpikir tingkat tinggi atau dikenal dengan istilah higher order thinking skill.

Higher order thinking skills menjadi salah satu prioritas dalam pembelajaran matematika di berbagai tingkatan sekolah. Siswa yang memiliki keterampilan berpikir tingkat tinggi akan mampu mengkonstruksi penjelasan, memberikan argumen dengan baik, mampu memecahkan masalah, mampu membuat dugaan serta memahami hal-hal yang rumit menjadi lebih sederhana. HOTS dalam pembelajaran (termasuk matematika) terbentuk melalui sebuah proses yang kontinu dan berkesinambungan yang tidak hanya berorientasi pada hasil akhir. Proses pembelajaran serta evaluasi yang diterapkan hendaknya dapat memfasilitasi siswa dalam mengembangkan kemampuan berpikir tingkat tingginya. Oleh karena itu,

5 Yee Mei Heong et al., "The Level of Marzano Higher Order Thinking Skillsamong Technical Education Students," International Journal of Social Science and Humanity 1, no. 2 (2011): 121-25, https://doi.org/10.7763/ijssh.2011.v1.20.

${ }^{6}$ Susan M Brookhart, How to Assess Higher-Order Thinking Skills in Your Slassroomin Your Classroom, Assess Thinking Higher-Order Skills, 2010.

${ }^{7}$ Brookhart.

${ }^{8}$ Lorin W. Anderson and David R. Krathwohl, A Taxonomy for Learning, Teaching, and Assessing, Longman New York, 2001. 
salah satu faktor yang dapat mendukung pengembangan hal tersebut adalah kemampuan profesional seorang guru.

Guru dipandang sebagai faktor yang penting dan menentukan keberhasilan pembelajaran ${ }^{9}$. Guru memegang peran penting dalam membantu siswa untuk menjadi pemikir dan pemecah masalah yang baik melalui berbagai inovasi pembelajaran. Hidayati ${ }^{10}$ mengemukakan bahwa selain perlu melatih diri untuk membuat soal-soal terbuka yang memadai, seorang guru juga perlu untuk mengimplementasikan suatu pendekatan atau model pembelajaran yang dapat mendorong siswa berpikir tingkat tinggi seperti pendekatan saintifik dan juga pendekatan problem based learning. Pada pembelajaran matematika, Turmudi11 menyatakan bahwa inovasi yang dilakukan meliputi tiga hal yakni bagaimana memahami matematika, bagaimana mengajar matematika dan bagaimana menilai pemahaman matematika. Dengan demikian, guru harus memiliki kesiapan serta kompetensi yang baik agar dapat memfasilitasi siswa mengembangkan keterampilan berfikir tingkat tingginya melalui kegiatan pembelajaran serta penyajian masalah-masalah yang relevan.

Pengetahuan guru tentang HOTS serta strategi pembelajarannya merupakan kunci untuk meraih kesuksesan dalam pendidikan ${ }^{12}$. Daryanto ${ }^{13}$ mengemukakan bahwa pemahaman guru mengacu pada kemampuan untuk untuk mengetahui dan mengerti apa yang diajarkan, apa yang dikomunikasikan serta dapat memanfaatkan isinya tanpa keharusan menghubungkannya dengan konteks lainnya. Dalam mendorong pengembangan pengetahuan yang dimiliki siswa, Guru harus mampu memahami serta menyajikan masalah yang memungkinkan siswa menggunakan keterampilan berfikir tingkat tingginya. Oleh karena itu, seorang guru tidak bisa hanya fokus pada pengembangan instrument penilaian saja, tanpa pemahaman dan pelaksanaan inovasi dalam kegiatan pembelajaran $^{14}$.

${ }^{9}$ Isti Hidayah and Sugiarto, "Model of Independent Working Group of Teacher and Its Effectiveness towards the Elementary School Teacher's Ability in Conducting Mathematics Learning," Procedia - Social and Behavioral Sciences 214 (December 2015): 43-50, https://doi.org/10.1016/j.sbspro.2015.11.591.

${ }^{10}$ Arini Ulfah Hidayati, "Melatih Keterampilan Berpikir Tingkat Tinggi Dalam Pembelajaran Matematika Pada Siswa Sekolah Dasar," Jurnal Terampil: Jurnal Pendidikan Dan Pembelajaran Dasar 4, no. 2 (2017): 143-56.

11 Turmudi, "Teachers ' Perception Toward Mathematics Teaching Innovation in Indonesian Junior High School: An Exploratory Factor Analysis," Journal of Mathematics Education 5, no. 1 (2012): 97-120.

${ }^{12}$ Heri Retnawati et al., "Teachers' Knowledge about Higher-Order Thinking Skills and Its Learning Strategy," Problems of Education in the 21st Century 76, no. 2 (2018): 215-30.

13 Daryanto and Syaiful Karim, "Pembelajaran Abad 21," Gaya Media, 2017.

14 Rafiq Badjeber and Jayanti Putri Purwaningrum, "Pengembangan Higher Order Thinking Skills Dalam Pembelajaran Matematika Di SMP," Guru Tua : Jurnal Pendidikan Dan 
Beberapa hasil penelitian mengungkap bahwa kompetensi guru mempengaruhi peningkatan kinerja guru dalam proses pembelajaran ${ }^{15,16}$. Namun, Retnawati, et. al ${ }^{17}$ melaporkan bahwa pengetahuan guru tentang HOTS, kemampuan guru untuk meningkatan HOTS siswa, serta kemampuan guru untuk mengukur HOTS siswa masih rendah, walau guru sudah memahami pentingnya HOTS dan mengajarkannya dengan menggunakan berbagai model pembelajaran inovatif. Hal ini sejalan dengan temuan Thompson bahwa guru matematika di USA mengalami kesulitan dalam menafsirkan keterampilan berfikir dalam Taksonomi Bloom dan membuat item tes untuk kemampuan berpikir tingkat tinggi ${ }^{18}$. Hasil penelitian Iskandar dan Senam ${ }^{19}$ menunjukkan bahwa kemampuan guru lulusan program studi Pendidikan Kimia UNY dalam mengembangkan soal berbasis HOTS hanya sebesar $13,9 \%$.

Berdasarkan uraian masalah yang dikemukakan di atas, artikel ini mencoba untuk mendeskripsikan profil pengetahuan guru SD khususnya yang berada di kota Palu tentang higher order thinking skill dalam pembelajaran matematika.

\section{Metode}

Penelitian yang dilakukan merupakan penelitian deskriptif dengan pendekatan kualitatif yang dimaksudkan untuk menggambarkan secara utuh pengetahuan guru mengenai higher order thinking skill. Kajian tentang profil pengetahuan higher order thinking skill guru SD dalam penelitian ini difokuskan pada dua aspek yaitu deskripsi pengetahuan guru tentang makna higher order thinking skill dan deskripsi pengetahuan tentang implementasi pembelajaran yang berorientasi higher order thinking skill. Subjek dalam penelitian ini terdiri dari 3 orang guru SD kelas atas (4, 5 dan 6) yang berada di Kota Palu. Pemilihan subjek tersebut dengan pertimbangan sebagai perwakilan pada setiap tingkatan kelas atas yang ada di sekolah dasar.

Pembelajaran 1, no. 1 (2018): 36-43, https://unisa-palu.ejournal.id/gurutua/article/view/9.

${ }^{15}$ Nursiah Sappaile, "Pengaruh Kompetensi Pedagogik, Kompetensi Profesional , Dan Sikap Profesi Guru Tehadap Kinerja Penilaian Guru Di Sekolah Dasar,” Jurnal Teknologi Pendidikan 19, no. 1 (2017): 47-58, https://doi.org/10.1080/08897077.2014.993491.

16 Tatan Zaenal Mutakin, "Pengaruh Kompetensi, Kompensasi, Dan Latar Belakang Terhadap Kinerja Guru," Formatif: Jurnal Ilmiah Pendidikan MIPA 3, no. 2 (2015): 145-56, https://doi.org/10.30998/formatif.v3i2.122.

17 Retnawati et al., "Teachers' Knowledge about Higher-Order Thinking Skills and Its Learning Strategy."

18 Tony Thompson, "Mathematics Teachers' Interpretation of Higher-Order Thinking in Bloom's Taxonomy," International Electronic Journal of Mathematics Education 3, no. 2 (2008): 96-108.

19 Dodi Iskandar and Senam Senam, "STUDI KEMAMPUAN GURU KIMIA SMA LULUSAN UNY DALAM MENGEMBANGKAN SOAL UAS BERBASIS HOTS," Jurnal Inovasi Pendidikan IPA 1, no. 1 (April 1, 2015): 65-72, https://doi.org/10.21831/jipi.v1i1.4533. 
Data hasil penelitian dikumpulkan mengggunakan kuesioner dan wawancara. Subjek penelitian terlebih dahulu diberikan kuesioner yang memuat item pertanyaan atau pernyataan tentang pengetahuan guru mengenai makna higher order thinking skill dan implementasinya dalam pembelajaran. Selanjutnya hasil jawaban pada kuesioner tersebut diverifikasi melalui wawancara untuk memperoleh gambaran yang lebih detail

Tahapan analisis data yang dilakukan mengacu pada model Miles dan Huberman ${ }^{20}$ yaitu data reduction (reduksi data), data display (penyajian data), dan conclusion drawing/verification (penarikan kesimpulan dan verifikasi). Data yang diperoleh dari hasil kuesioner dan wawancara dari masing-masing subjek selanjutnya ditranskrip. Data yang tidak berkaitan dengan tujuan penelitian akan direduksi dengan cara membuat ikhtisar, menyederhanakan data yang diperoleh serta membuang data yang tidak relevan. Selanjutnya, data yang telah direduksi dikelompokkan dan disajikan untuk dapat dimaknai secara umum. Pemeriksaan keabsahan data dilakukan dengan menggunakan metode triangulasi yaitu triangulasi metode dengan membandingkan data jawaban kuesioner dan hasil wawancara ${ }^{21}$. Apabila data yang diperoleh dari hasil wawancara dan kuesioner konsisten, maka data tersebut dianggap kredibel. Pada tahap akhir, dilakukan penyimpulan sesuai profil yang ingin dideskripsikan

\section{Hasil dan Diskusi}

Subjek penelitian dipilih berdasarkan pertimbangan bahwa masingmasing guru mewakili setiap tingkatan pada kelas atas di sekolah Dasar. Subjek penelitian tersebut selanjutnya diberi simbol S1, S2 dan S3 untuk memudahkan proses analisis data. Para subjek diberikan kuesioner yang memuat indikator tentang pemahaman makna higher order thinking skill dan implementasi pembelajaran yang berorientasi higher order thinking skill. Setelah itu, peneliti melakukan wawancara langsung terhadap ketiga subjek penelitian menggunakan pedoman yang telah disusun. Hasil proses triangulasi menunjukkan kekonsistenan data yang diperoleh sehingga dapat dikatakan kredibel.

Dalam aspek pengetahuan tentang pemaknaan higher order thinking skilldiperoleh temuan bahwa subjek S1 menyatakan bahwa HOTS merupakan suatu hal yang menuntut pendidik untuk berperan aktif dalam mengkonstruksi pemahaman siswa menuju proses berpikir secara kompleks. Subjek S2 mengemukakan bahwa HOTS merupakan soal-soal yang membutuhkan pikiran tingkat tinggi. Sedangkan menurut subjek S3 HOTS

${ }^{20}$ Sugiyono, Metodologi Penelitian Kuantitatif, Kualitatif, Dan R\&D, CV Alfabeta, 2013.

${ }^{21}$ Lexy J. Moleong, "Metodologi Penelitian Kualitatif (Edisi Revisi)," in PT. Remaja Rosda Karya, 2017. 
merupakan keterampilan berpikir kritis. Hal ini menunjukkan bahwa para subjek memaknai HOTS secara berbeda-beda yakni sebagai keterampilan, instrumen penilaian dan proses pembelajaran. Selanjutnya dalam menentukan level kognitif HOTS sesuai taksonomi Bloom, hanya subjek S1 yang dapat menyatakan dengan lengkap dan benar. Subjek S2 menyebutkan level yang dimaksud meliputi level menalar dan menganalisis sedangkan subjek S3 hanya memaparkan kognitif merupakan keterampilan yang berkaitan dengan pengetahuan.

Aspek pengetahuan tentang implementasi pembelajaran yang berorientasi HOTS merepresentasikan pengetahuan guru dalam mengelola kegiatan pembelajaran. Terdapat tiga tahapan utama dalam proses pembelajaran yakni perencanaan, pelaksanaan dan evaluasi. Ketiga komponen tersebut merupakan indikator utama kajian ini dalam kaitannya dengan implementasi pembelajaran yang berorientasi HOTS.

Tahap perencanaan pembelajaran yang dikaji meliputi perumusan tujuan pembelajaran, serta pengetahuan tentang model atau metode pembelajaran yang relevan untuk mendorong pegembangan HOTS siswa. Dalam menentukan tujuan pembelajaran matematika di Sekolah Dasar yang berorientasi HOTS, sesuai hasil kuesioner diperoleh temuan sebagai berikut

Tabel 1. Contoh Rumusan Tujuan Pembelajaran

\begin{tabular}{ccl}
\hline No & Subjek & Contoh Rumusan Tujuan Pembelajaran yang dibuat \\
\hline 1 & S1 & $\begin{array}{l}\text { Peserta didik dapat membuat jaring-jaring kubus dan } \\
\text { jaring-jaring balok. }\end{array}$ \\
\hline 2 & S2 & $\begin{array}{l}\text { Peserta didik dapat menghitung jumlah bangun } \\
\text { gabungan dlm sebuah segitiga bertumpuk }\end{array}$ \\
\hline 3 & S3 & $\begin{array}{l}\text { Mendeskripsikan proses pengembangan desain } \\
\text { pembelajaran matematika yang berorientasi hots } \\
\text { pada materi pecahan berpenyebut tidak sama }\end{array}$ \\
\hline
\end{tabular}

Berdasarkan hasil yang ditunjukkan pada Tabel 1 dan proses wawancara, diperoleh data bahwa ketiga subjek belum dapat merumuskan tujuan pembelajaran yang memuat higher order thinking skill. Namun, ketiga subjek sudah memahami model atau metode pembelajaran yang dapat mendorong peningkatan HOTS siswa diantaranya discovery learning, inquiry learning dan problem based learning.

Pada tahapan pelaksanaan pembelajaran, ketiga subjek relatif sering dalam mengaitkan materi yang sedang dipelajari dengan konteks dalam kehidupan sehari-hari. Namun, di sisi lain para subjek masih minim dalam memfasilitasi siswa untuk menuangkan gagasan atau ide dalam proses pembelajaran, memberikan tugas atau masalah yang berbasis proyek mandiri 
atau berkelompok, serta memfasilitasi siswa dalam membuat kesimpulan secara mandiri di setiap akhir kegiatan pembelajaran. Proses pembelajaran yang diterapkan lebih banyak berpusat pada guru. Berikut disajikan potongan jawaban wawancara subjek S2 terkait masalah proses pembelajaran yang dilakukan.

Saya dalam mengajar lebih banyak menjelaskan secara langsung kepada siswa. Banyak kendala yang saya rasakan dan hadapi jika meminta siswa untuk bisa secara mandiri memahami materi yang dipelajari utamanya yang berkaiatan dengan konteks higher order thinking skill. Diantaranya karena sebagian besar tingkat pemahaman mereka masih pada level LOTS (Low Order Thinking Skill).

Dalam pelaksanaan evaluasi yang menjadi indikator dalam penelitian ini adalah kemampuan subjek dalam menyusun soal higher order thinking skill. Berdasarkan hasil kuesioner, berikut ini disajikan temuan yang diperoleh dalam indikator tersebut.

Tabel 2. Contoh Soal

\begin{tabular}{|c|c|c|}
\hline No & Subjek & Contoh Soal yang dibuat \\
\hline 1 & S1 & $\begin{array}{l}\text { Seorang pedagang sembako memiliki } 35 \text { karung } \\
\text { gula pasir dan setiap karung berisi } 50 \mathrm{~kg} \text {. } \\
\text { Apabila semua gula pasir dipindahkan ke dalam } \\
\text { kantong plastik yang masing-masing berisi } 10 \\
\text { kg, maka berapa kantong yg harus disediakan? }\end{array}$ \\
\hline 2 & S2 & $\begin{array}{l}\text { Andi sedang mengadakan perjalanan dengan } \\
\text { sepeda motor dari Palu menuju Ampana. Dia } \\
\text { berangkat pukul } 05.00 \text { dan sampai tujuan pukul } \\
\text { 19.00. Dalam perjalanan dia beristirahat selama } \\
30 \text { menit. Berapa lama perjalanan yang } \\
\text { ditempuh Andi? }\end{array}$ \\
\hline 3 & S3 & $\begin{array}{l}\text { Jari-jari roda sebuah sepeda adalah } 28 \mathrm{dm} \text {. } \\
\text { Berapa meter jarak yang ditempuh oleh sepeda } \\
\text { jika roda berputar sebanyak } 150 \text { kali? }\end{array}$ \\
\hline
\end{tabular}

Berdasarkan hasil yang disajikan dalam tabel 2, tampak bahwa subjek S1 dapat menyusun soal HOTS dengan level C4 (analisis). Namun, subjek S2 dan S3 hanya membuat soal dengan kategori low order thinking skill. Soal yang disusun oleh subjek S2 merupakan soal dengan level C2 (memahami) karena hanya mengukur pemahaman siswa tentang konsep jarak, sedangkan subjek S3 membuat soal dalam level C3 (mengaplikasikan) karena mengukur 
kemampuan siswa dalam menerapkan konsep keliling lingkaran dalam menyelesaikan masalah kontekstual.

Secara umum, berdasarkan penelitian yang dilakukan diperoleh data bahwa para subjek masih bingung dalam memaknai higher order thinking skill sehingga menghasilkan jawaban yang berbeda-beda. Selain itu, mereka belum dapat menentukan level kognitif HOTS sesuai taksonomi Bloom dengan baik. Hal ini berdampak pula pada pengetahuan mereka tentang implementasi HOTS dalam proses pembelajaran. Pada tahap perencanaan pembelajaran, ketiga subjek subjek belum dapat merumuskan tujuan pembelajaran yang memuat HOTS, meskipun mereka telah memahami model atau metode pembelajaran yang relevan untuk diterapkan dalam meningkatkan HOTS siswa. Pada tahap pelaksanaan pembelajaran, ketiga subjek juga relatif minim melakukan hal-hal yang dapat mendukung dan mendorong peningkatan HOTS siswa. Selanjutnya pada tahap evaluasi, hanya seorang subjek yang dapat mengkonstruksi instrumen penelitian yang memuat HOTS, sedangkan dua subjek lainnya menyusun soal yang hanya tergolong dalam level C2 dan C3 pada taksonomi Bloom yang merupakan level low order thinking skill.

Hasil yang diperoleh dalam penelitian ini sejalan dengan temuan Retnawati, et. al ${ }^{22}$ yang menyebutkan bahwa tidak semua guru memahami HOTS dengan baik. Guru masih tidak dapat membedakan HOTS sebagai kemampuan, keterampilan, strategi belajar, metode pembelajaran atau proses pembelajaran ${ }^{23}$. Hal ini juga selaras dengan Thompson ${ }^{24}$ yang mengemukakan bahwa dalam mendefinisikan HOTS terdapat beragam jawaban yang diberikan oleh guru. Mereka mendefinisikan HOTS berdasarkan banyaknya langkah yang harus ditempuh dalam menyelesaikan suatu masalah serta merupakan tingkat kesulitan suatu soal. Rendahnya pengetahuan guru tentang implementasi HOTS dalam proses pembelajaran matematika diantaranya disebabkan belum semua guru memahami pentingnya pemberdayaan HOTS 25. Hal-hal ini tentu dapat mempengaruhi optimalisasi hasil belajar yang diperoleh siswa ${ }^{26}$.

22 Retnawati et al., "Teachers' Knowledge about Higher-Order Thinking Skills and Its Learning Strategy."

${ }^{23}$ Retnawati et al.

${ }^{24}$ Thompson, "Mathematics Teachers' Interpretation of Higher-Order Thinking in Bloom's Taxonomy."

${ }^{25}$ Femmy Kawuwung, "Profil Guru, Pemahaman Kooperatif Nht, Dan Kemampuan Berpikir Tingkat Tinggi Di SMP Kabupaten Minahasa Utara," El-Hayah 1, no. 4 (April 16, 2012): 157-66, https://doi.org/10.18860/elha.v1i4.1693.

${ }^{26}$ Makbule Gozde Didis et al., "Exploring Prospective Secondary Mathematics Teachers' Interpretation of Student Thinking through Analysing Students' Work in Modelling," Mathematics Education Research Journal 28, no. 3 (September 16, 2016): 349-78, https://doi.org/10.1007/s13394-016-0170-6. 


\section{Kesimpulan}

Berdasarkan analisis hasil penelitian mengenai pengetahuan guru Sekolah Dasar tentang higher order thinking skill dalam pembelajaran matematika dapat disimpulkan bahwa pengetahuan guru tentang makna higher order thinking skill masih rendah. Tidak semua guru mengetahui level kognitif HOTS sesuai Taksonomi Bloom serta memaknai HOTS secara beragam yakni sebagai keterampilan, instrumen penilaian dan proses pembelajaran. Selain itu, pengetahuan guru tentang implementasi pembelajaran matematika yang berorientasi higher order thinking skill juga masih rendah. Pada tahap perencanaan pembelajaran, guru belum dapat merumuskan tujuan pembelajaran yang memuat HOTS, walau telah mengetahui model atau metode pembelajaran yang relevan untuk diterapkan dalam mendorong pengembangan HOTS siswa. Pada tahap pelaksanaan pembelajaran, guru masih minim dalam melakukan hal-hal yang memfasiltasi peningkatan HOTS siswa. Pada tahap evaluasi, kemampuan guru dalam menyusun instrumen penilaian HOTS masih rendah.

Temuan penelitian ini menunjukkan bahwa profil pengetahuan guru SD tentang higher order thinking skill dalam pembelajaran matematika khususnya tentang pemahaman makna serta implemenyasinya dalam pembelajaran perlu mendapat perhatian lebih. Dibutuhkan kegiatan-kegiatan oleh lembaga terkait atau penelitian-penelitian lainnya yang memfokuskan pada pengembangan pengetahuan guru SD tentang higher order thinking skill.

\section{Daftar Pustaka}

Anderson, Lorin W., and David R. Krathwohl. A Taxonomy for Learning, Teaching, and Assessing. Longman New York, 2001.

Badjeber, Rafiq, and Jayanti Putri Purwaningrum. "Pengembangan Higher Order Thinking Skills Dalam Pembelajaran Matematika Di SMP." Guru Tua: Jurnal Pendidikan Dan Pembelajaran 1, no. 1 (2018): 36-43. https://unisa-palu.e-journal.id/gurutua/article/view/9.

Brookhart, Susan M. How to Assess Higher-Order Thinking Skills in Your Slassroomin Your Classroom. Assess Thinking Higher-Order Skills, 2010. Daryanto, and Syaiful Karim. "Pembelajaran Abad 21." Gaya Media, 2017.

Didis, Makbule Gozde, Ayhan Kursat Erbas, Bulent Cetinkaya, Erdinc Cakiroglu, and Cengiz Alacaci. "Exploring Prospective Secondary Mathematics Teachers' Interpretation of Student Thinking through Analysing Students' Work in Modelling." Mathematics Education Research Journal 28, no. 3 (September 16, 2016): 349-78. https://doi.org/10.1007/s13394-016-0170-6.

Gronmo, Liv Sissel, Mary Lindquist, Alka Arora, and Ina V. S. Mullis. "TIMMS 2015 Mathematics Framework." TIMSS 2015 International Results in Mathematics, 2016.

Hendriana, Heris, and Utari Sumarmo. Penilaian Pembelajaran Matematika. PT 
Refika Aditama, 2017.

Heong, Yee Mei, Widad Binti Othman, Jailani Bin Md Yunos, Tee Tze Kiong, Razali Bin Hassan, and Mimi Mohaffyza Binti Mohamad. "The Level of Marzano Higher Order Thinking Skillsamong Technical Education Students." International Journal of Social Science and Humanity 1, no. 2 (2011): 121-25. https://doi.org/10.7763/ijssh.2011.v1.20.

Hidayah, Isti, and Sugiarto. "Model of Independent Working Group of Teacher and Its Effectiveness towards the Elementary School Teacher's Ability in Conducting Mathematics Learning." Procedia - Social and Behavioral $\begin{array}{llll}\text { Sciences } 214 & \text { (December } 2015): 50 .\end{array}$ https://doi.org/10.1016/j.sbspro.2015.11.591.

Hidayati, Arini Ulfah. "Melatih Keterampilan Berpikir Tingkat Tinggi Dalam Pembelajaran Matematika Pada Siswa Sekolah Dasar." Jurnal Terampil: Jurnal Pendidikan Dan Pembelajaran Dasar4, no. 2 (2017): 143-56.

Iskandar, Dodi, and Senam Senam. "Studi Kemampuan Guru Kimia Sma Lulusan Uny Dalam Mengembangkan Soal Uas Berbasis Hots." Jurnal Inovasi Pendidikan IPA 1, no. 1 (April 1, 2015): 65-72. https://doi.org/10.21831/jipi.v1i1.4533.

Kawuwung, Femmy. "Profil Guru, Pemahaman Kooperatif Nht, Dan Kemampuan Berpikir Tingkat Tinggi Di SMP Kabupaten Minahasa Utara." El-Hayah 1, no. 4 (April 16, 2012): 157-66. https://doi.org/10.18860/elha.v1i4.1693.

Kusumaningrum, Maya, and Adul Aziz Saefudin. "Mengoptimalkan Kemampuan Berpikir Matematika Melalui Pemecahan Masalah Matematika." Prosiding Kontribusi Pendidikan Matematika Dan Matematika Dalam Membangun Karakter Guru Dan Siswa, 2012.

Moleong, Lexy J. "Metodologi Penelitian Kualitatif (Edisi Revisi)." In PT. Remaja Rosda Karya, 2017.

Mutakin, Tatan Zaenal. "Pengaruh Kompetensi, Kompensasi, Dan Latar Belakang Terhadap Kinerja Guru." Formatif: Jurnal IImiah Pendidikan

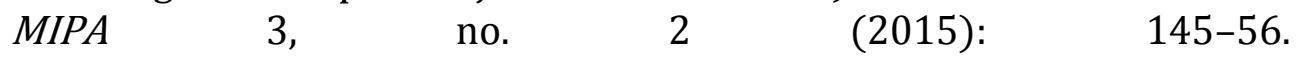
https://doi.org/10.30998/formatif.v3i2.122.

Retnawati, Heri, Hasan Djidu, Kartianom, Ezi Apino, and Risqa D. Anazifa. “Teachers' Knowledge about Higher-Order Thinking Skills and Its Learning Strategy." Problems of Education in the 21st Century 76, no. 2 (2018): 215-30.

Sappaile, Nursiah. "Pengaruh Kompetensi Pedagogik, Kompetensi Profesional , Dan Sikap Profesi Guru Tehadap Kinerja Penilaian Guru Di Sekolah Dasar." Jurnal Teknologi Pendidikan 19, no. 1 (2017): 47-58. https://doi.org/10.1080/08897077.2014.993491.

Skills, Partnership for 21St Century. "Framework for 21st Century Learning." Partnership for 21st Century Skills, 2011. https://doi.org/http://www.21stcenturyskills.org/documents/framew ork_flyer_updated_jan_09_final-1.pdf.

Sugiyono. Metodologi Penelitian Kuantitatif, Kualitatif, Dan R\&D. CV Alfabeta, 2013.

Thompson, Tony. "Mathematics Teachers' Interpretation of Higher-Order 
144 Rafiq Badjeber, dkk /Al-Khwarizmi: Jurnal Pendidikan Matematika dan Ilmu Pengetahuan Alam, Oktober-2020, Vol.8, No.2, hal.133-144

Thinking in Bloom's Taxonomy." International Electronic Journal of Mathematics Education 3, no. 2 (2008): 96-108.

Turmudi. "Teachers ' Perception Toward Mathematics Teaching Innovation in Indonesian Junior High School : An Exploratory Factor Analysis." Journal of Mathematics Education 5, no. 1 (2012): 97-120. 